\title{
Filmes compostos de gelatina, triacetina, ácido esteárico ou capróico: efeito do pH e da adição de surfactantes sobre a funcionalidade dos filmes
}

Composite films made with gelatin, tracetin, stearic and caproic acids: effect of $\mathrm{pH}$ and surfactants addition on the functionality of films

\author{
Taciana DAVANÇO ${ }^{1}$, Patrícia TANADA-PALMU ${ }^{1}$, Carlos GROSSO ${ }^{1 *}$
}

\begin{abstract}
Resumo
O desenvolvimento de biofilmes tem crescido devido à possibilidade de substituição parcial de materiais plásticos não biodegradáveis. Proteínas e polissacarídeos têm sido utilizados para a produção de filmes com boas propriedades mecânicas. Porém, filmes a partir desses materiais apresentam alta permeabilidade ao vapor de água. Uma alternativa usada para diminuir a permeabilidade ao vapor de água dos filmes é a incorporação de substâncias hidrofóbicas na composição da solução filmogênica, porém essa incorporação não ocorre de maneira homogênea. Com o objetivo de melhorar a incorporação das substâncias hidrofóbicas (ácido esteárico e ácido capróico) na matriz protéica (gelatina) do filme foram adicionados os surfactantes (SDS e Tween 80), que são substâncias capazes de interagir com a proteína e com o ácido graxo, tornando a matriz filmogênica menos heterogênea. O efeito do $\mathrm{pH}$ também foi estudado, com a finalidade de observar se este exerce influência na homogeneidade da matriz filmogênica. A adição do ácido esteárico aos filmes de gelatina foi mais eficiente na redução da permeabilidade ao vapor de água do que o ácido capróico. A adição do surfactante SDS reduziu a permeabilidade ao vapor de água dos filmes contendo ácido esteárico, ou ácido capróico. O ajuste de $\mathrm{pH}$ nos filmes sem adição de surfactantes também produziu matrizes mais homogêneas.

Palavras-chave: biofilmes; gelatina; ácido capróico; ácido esteárico; SDS (lauril sulfato de sódio); Tween 80.
\end{abstract}

\begin{abstract}
The development of biofilms has grown considering the possibility of partial substitution of plastic materials which are not biodegradable. Proteins and polysaccharides have been used to produce films with good mechanical properties. However, films produced with these materials present a high permeability in water vapor. An alternative to improve the water vapor barrier of films is to incorporate hydrophobic substances (stearic and caproic fatty acids) in the composition of the filmogenic solution, however this incorporation does not occur homogeneously. Thus, to improve the incorporation of hydrophobic substances in the protein matrix of the film, surfactants (SDS and Tween 80) were added. They are compounds that improve the interaction between the protein and the fatty acids, producing a less heterogeneous filmogenic matrix. The effect of $\mathrm{pH}$ was also studied, with the purpose of observing if it influences the homogeneity of the filmogenic matrix. The addition of stearic acid to the gelatin-based films was more efficient in reducing the water vapor permeability than the caproic acid. Adding surfactant SDS reduced water vapor permeability of both films, with stearic acid or caproic acid. Adjusting the pH to the films with no surfactants produced more homogeneous matrices.

Keywords: edible film; gelatin; caproic acid; stearic acid; SDS (sodium lauryl sulphate); Tween 80.
\end{abstract}

\section{Introdução}

A poluição ambiental causada pela deposição de materiais de embalagem não renováveis no meio ambiente demanda alternativas para seu controle e ou eliminação. Assim, surgiu o interesse em desenvolver biofilmes com características de embalagens biodegradáveis, que não causem danos ao meio ambiente e que adicionalmente possam melhorar a qualidade dos produtos alimentícios.

Os biofilmes geralmente são elaborados a partir de proteínas, polissacarídios, lipídios ou da combinação deles. Para melhorar as propriedades de barreira dos biofilmes, a incorporação de lipídios surge como alternativa interessante e tem sido estudada por vários pesquisadores como GONTARD et al. ${ }^{12}$; BALDWIN et al. ${ }^{5}$ e BERTAN ${ }^{7}$. Coberturas e biofilmes a base de lipídios produzidos com ceras, óleos ou ácidos graxos são efetivos como barreira à umidade, devido ao seu caráter hidrofóbico. Coberturas e biofilmes feitos de polissacarídeos (celulose, pectina, amido, alginatos, quitosana e gomas) apre-

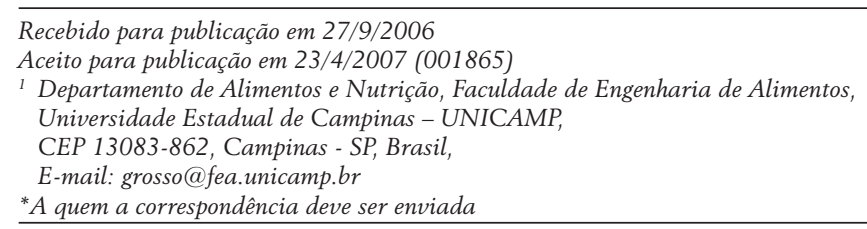

sentam boa barreira a gases $\left(\mathrm{O}_{2}\right.$ e $\left.\mathrm{CO}_{2}\right)$, mas não a água, provavelmente relacionada à alta polaridade deste tipo de filme. As coberturas e biofilmes a partir de proteínas (caseína, gelatina, soja, zeína, glúten e albumina de ovo) são boas barreiras ao $\mathrm{O}_{2}$ $\mathrm{e} \mathrm{CO}_{2}$ em ambientes com baixa umidade relativa, mas não em alta umidade devido à susceptibilidade do filme em absorver umidade e se dissolver. Filmes e coberturas compostos ou de duas camadas estão sendo investigados, a fim de melhorar as características de permeabilidade, força, flexibilidade e valor nutricional ${ }^{1}$. Quando se adiciona um componente hidrofóbico à suspensão formadora do filme, produzem-se filmes compostos, nos quais o componente lipídico atua como barreira ao vapor de água, e a proteína ou polissacarídeo fornecem a barreira ao oxigênio e as características mecânicas necessárias a um bom filme ${ }^{2}$.

A natureza química dos lipídios modifica as propriedades dos biofilmes, como o comprimento da cadeia carbônica, onde, quanto maior o número de carbonos na estrutura lipídica, mais difícil é a incorporação dos compostos lipídicos na solução protéica. Por exemplo, o ácido araquídico (22C) possui maior permeabilidade ao vapor de água que os ácidos palmítico (16C) e esteárico (18C), o que pode ser explicado pelo fato de que a cadeia longa do lipídio sugere uma estrutura mais heterogê- 
nea ${ }^{21}$. Os surfactantes são compostos que apresentam atividade na superfície da interface entre duas fases, tais como ar-água, óleo-água, e na superfície de sólidos. Também são conhecidos como agentes tenso-ativos. Tais compostos caracterizam-se por possuir duas regiões distintas na mesma molécula: uma região polar hidrofílica e outra região não-polar hidrofóbica ${ }^{20}$. Segundo BALDWIN et al. ${ }^{5}$, agentes emulsionantes ou surfactantes são freqüentemente necessários para melhorar a estabilidade das partículas de lipídios na matriz protéica.

A variação do $\mathrm{pH}$ pode causar a diminuição da capacidade de emulsificação e de formar filme. PÉREZ-GAGO e KROCHTA ${ }^{22}$ obtiveram filmes à base de isolado protéico de soro de leite $\mathrm{e}$ cera de abelha, em pH 4,0-5,0, quebradiços e com defeitos, caracterizados por uma maior permeabilidade ao vapor de água em relação ao $\mathrm{pH}$ neutro e básico. Os autores atribuíram o aumento da viscosidade da solução filmogênica em $\mathrm{pH}$ ácido a uma maior agregação das proteínas, impedindo a interação proteína-proteína na matriz filmogênica, assim reduzindo a mobilidade e a interligação das partículas lipídicas com a cadeia protéica.

O objetivo deste trabalho foi desenvolver filmes à base de gelatina, triacetina, ácido esteárico ou ácido capróico com e sem o ajuste de pH e surfactantes SDS e Tween 80 e caracterizar os filmes quanto à permeabilidade ao vapor de água, propriedades mecânicas, solubilidade em água, opacidade e características morfológicas (microscopia ótica, microscopia eletrônica de varredura e microscopia confocal de varredura a laser).

\section{Material e métodos}

\subsection{Materiais}

Gelatina tipo A (bloom $=240$, viscosidade $35 \mathrm{mps}$, umidade $=9,8 \%$ e diâmetro de partícula $=6$ mesh), gentilmente cedida pela empresa GELITA DO BRASIL; triacetina cedida pela RHODIA, ácidos esteárico e capróico (Vetec), Lauril sulfato de sódio; lote: 093 K0100 (Sigma) e Tween 80; lote: 76769 (Vetec).

\subsection{Métodos}

\section{Testes preliminares}

Inicialmente foram realizados testes preliminares na preparação dos filmes com variação no $\mathrm{pH}$, temperatura e concentração de surfactante. Foram testadas duas soluções filme-formadoras contendo gelatina ( 10 g para $100 \mathrm{~mL}$ de água destilada), triacetina ( $10 \%$, em relação à massa seca de gelatina) e ácido esteárico (10\%, em relação à massa seca da gelatina) ou gelatina ( $10 \mathrm{~g}$ para $100 \mathrm{~mL}$ de água destilada), triacetina (10\%, em relação à massa seca de gelatina) e ácido capróico (5\%, em relação à massa seca de gelatina). Estes estudos foram feitos a pH 4,5 (pH inicial da solução) e a pH 7,5 (ajustado com $\mathrm{NaOH} 0,1$ mol. $\left.\mathrm{L}^{-1}\right)$. Para testar a solubilidade dos compostos lipídicos, a temperatura foi variada gradualmente de 25 a $80^{\circ} \mathrm{C}$ e a suspensão observada visualmente para a obtenção de uma solução transparente. Após esta etapa, foram realizados novos testes com adição de surfactantes em diferentes concentrações do SDS (lauril sulfato de sódio) e Tween 80 individualmente (de 10 a 100\%, em relação à massa seca da gelatina) com a mesma variação de temperatura e de $\mathrm{pH}$ estudada para o filme sem surfactantes, para definir as melhores concentrações de surfactantes em cada formulação com a produção de soluções transparentes observadas visualmente.

Elaboração dos filmes de gelatina, triacetina, ácido capróico ou ácido esteárico com e sem o ajuste de pH

A solução filme-formadora (solução A) foi obtida hidratando-se 10 g de gelatina em 100 mL de água destilada, por 1 hora, em temperatura ambiente. Após esse período, a solução foi solubilizada a $70{ }^{\circ} \mathrm{C}$, em banho termostático, por 10 minutos. Após completa solubilização, foram adicionados a triacetina ( $10 \%$ em relação ao peso da massa seca de gelatina) e o ácido esteárico ( $10 \%$ em relação ao peso da massa seca de gelatina) ou o ácido capróico (5\% em relação ao peso da massa seca de gelatina). Em seguida, os filmes com ajuste de $\mathrm{pH}$ tiveram seu $\mathrm{pH}$ final ajustado para 7,5. As soluções foram aplicadas sobre placas plaxiglass de $15 \times 15 \mathrm{~cm}$. O controle da espessura constante foi obtido através do ajuste do volume da solução filmogênica posteriormente seca à temperatura ambiente (aproximadamente $25-30{ }^{\circ} \mathrm{C}$ ) por 24 horas. Após a secagem, os filmes foram removidos das placas de plaxiglass e permaneceram em dessecadores mantidos a $25{ }^{\circ} \mathrm{C}$ e $52+2 \%$ de umidade relativa (URE), durante 48 horas antes do início das análises.

\section{Elaboração dos filmes de gelatina, triacetina, lauril sulfato de sódio ou Tween 80 e ácido esteárico}

A solução filme-formadora A foi preparada e, após completa solubilização (obtida a aproximadamente $70{ }^{\circ} \mathrm{C}$ ), foram adicionados a triacetina $(10 \%$ em relação à massa seca de gelatina), o lauril sulfato de sódio (60 e 70\% com pH ajustado, em relação à massa seca de gelatina) ou 100\% de Tween (em relação à massa seca de gelatina) e o ácido esteárico (10\% em relação à massa seca de gelatina). Essas concentrações dos surfactantes foram definidas através dos testes preliminares.

\section{Elaboração dos filmes de gelatina, triacetina, lauril sulfato de sódio ou Tween 80 e ácido capróico}

A solução filme-formadora A foi preparada e após completa solubilização, foram adicionados a triacetina ( $10 \%$ em relação ao peso da massa seca de gelatina), o lauril sulfato de sódio (10\% em relação à massa seca de gelatina) ou o Tween 80 (10\% em relação à massa seca da gelatina, com e sem o ajuste de $\mathrm{pH}$ ) e o ácido capróico (5\% em relação ao peso da massa seca de gelatina). Essas concentrações dos surfactantes foram definidas através dos testes preliminares.

\subsection{Caracterização dos filmes}

\section{Espessura}

A espessura foi obtida através da média dos valores de dez pontos aleatórios em diferentes segmentos do filme, utilizando- 
se um micrômetro digital (Model MDC-25M, Mitutoyo, MFG, Japan, resolução 0,001 mm).

\section{Permeabilidade ao vapor de água}

A permeabilidade ao vapor de água (PVA) dos filmes foi determinada gravimetricamente a $25^{\circ} \mathrm{C}$, de acordo com o método padrão E-96-95 da $\mathrm{ASTM}^{3}$. As amostras de cada filme foram seladas com parafina em células de permeação de alumínio, contendo cloreto de cálcio. Essas células foram acondicionadas em dessecadores a $25{ }^{\circ} \mathrm{C}$ e $75 \%$ UR. A partir do ganho de peso do cloreto de cálcio, medido em intervalos de 24 horas, durante 7 dias, foi possível determinar o vapor de água transferido através do filme. As análises foram realizadas em triplicata.

\section{Propriedades mecânicas}

A resistência à tração e a porcentagem de elongação na ruptura (Elon) dos filmes foram determinadas utilizando-se um texturômetro TA-XT2 (SMS, Surrey, UK) de acordo com o método padrão ASTM D 882 4 . As amostras de filmes foram cortadas, apresentando $100 \mathrm{~mm}$ de comprimento e $25 \mathrm{~mm}$ de largura. A distância inicial de separação das garras e velocidade de realização do teste foram fixadas em 50 e 3 mm/segundo, respectivamente.

A resistência à tração foi calculada dividindo-se a força máxima no rompimento do filme, pela área de secção transversal. A elongação na ruptura foi determinada dividindo-se a distância final de separação da "probe" pela distância inicial de separação $(50 \mathrm{~mm})$, multiplicada por $100^{15}$. A média das espessuras requeridas para o cálculo da área seccional foi determinada utilizando-se 5 medidas obtidas ao longo do filme, após o período de acondicionamento à temperatura de $25{ }^{\circ} \mathrm{C}$, $52 \pm 2 \%$ de umidade relativa, durante 48 horas.

\section{Opacidade}

A opacidade (\%) dos filmes foi determinada utilizando-se colorímetro Hunterlab (Colorquest II, Faifax). As determinações foram feitas em triplicata após a calibração do colorímetro com um fundo padrão branco e um fundo padrão negro. A opacidade foi determinada através do software disponível no aparelho ${ }^{14}$.

\section{Microscopia eletrônica de varredura}

A microestrutura da superfície dos filmes foi avaliada utilizando-se microscópio eletrônico de varredura (JEOL SCANNING MICROSCOPE - JMS-5800LV) a $10 \mathrm{kV}$. Os filmes foram colocados em dessecadores contendo sílica gel $\left(25^{\circ} \mathrm{C}\right)$, por um período de sete dias sendo então fragmentados. As amostras dos filmes fragmentadas foram fixadas em suporte ("stubs") de alumínio, com fita condutiva de cobre. Após esse período, as amostras foram recobertas com ouro (SPUTTER COATER BALZERS-SCD 050, Baltec, Lichtenstein), a $25{ }^{\circ} \mathrm{C} \mathrm{e}$ pressão de $2 \times 10^{-5}$ Torr por 180 segundos.

\section{Microscopia confocal de varredura a laser (MCLV)}

Os filmes foram também avaliados utilizando-se microscopia de varredura laser confocal em microscópio Olympus
LSM-Fluoview versão 3.2 (OLYMPUS, Tókio, Japão). A gelatina solubilizada após hidratação foi corada com o corante FITC (isotiocianato de fluoresceína), segundo metodologia proposta por LAMPRECHT et al. ${ }^{16}$, com a concentração modificada (50 $\mu 1.2,5 \mathrm{~g}^{-1}$ proteína). Após a adição, a solução de proteína contendo o corante foi agitada com agitação magnética lenta sob aquecimento de $40^{\circ} \mathrm{C}$ por uma hora antes de ser utilizada. Em seguida, a triacetina e os ácidos graxos, esteárico (10\%) e capróico (5\%), foram corados com o corante "NILE RED" (1 mg.30 g $\mathrm{g}^{-1}$ de substância hidrofóbica), segundo a metodologia proposta por LAMPRECHT et al. ${ }^{16}$. Passado o tempo necessário para o corante FITC reagir com a proteína, foram adicionadas as substâncias hidrofóbicas previamente coradas à solução de gelatina corada, sob agitação magnética até a homogeneização. As soluções filme-formadoras coradas foram levadas a outro banho-maria a $60-70{ }^{\circ} \mathrm{C}$ por 30 minutos sob agitação leve. Completada a preparação, a solução filme-formadora foi aplicada então sobre as placas plaxiglass secas e acondicionadas como na etapa de elaboração dos filmes.

\section{Análise Estatística}

As análises estatísticas de variância (ANOVA) foram realizadas utilizando-se o programa estatístico Statistical Analytical System $^{25}$. As diferenças significativas entre as médias foram identificadas através do teste de Tukey $(\mathrm{p}<0,05)$.

\section{Resultados e discussão}

\subsection{Testes preliminares para a definição da concentração de surfactante}

Através dos testes preliminares, definiu-se a concentração dos surfactantes para cada filme. Assim, para o filme composto com ácido esteárico (18C) somente a concentração de $100 \%$ de Tween 80 (em relação à massa seca de gelatina) tornou a solução transparente e para o lauril sulfato de sódio (SDS), foi necessário o ajuste de pH e a concentração de $60 \%$ ou $70 \%$ (em relação à massa seca de gelatina). Já para o filme composto com ácido capróico (6C), a adição de $10 \%$ de Tween 80 ou de $10 \%$ de SDS foi suficiente para a obtenção de soluções transparentes.

\subsection{Permeabilidade ao vapor de água}

O filme composto, sem variação de $\mathrm{pH}$, com ácido esteárico apresentou permeabilidade ao vapor de água (PVA) significativamente $(\mathrm{p} \leq 0,05)$ menor que os filmes compostos com ácido capróico, como pode ser observado na Tabela 1. Isso pode ter sido devido à maior concentração do ácido esteárico (10\% em relação à massa seca de gelatina) utilizada em relação ao ácido capróico ( $5 \%$ em relação à massa seca de gelatina), ou também devido ao tamanho maior da cadeia de ácido esteárico comparado com o ácido capróico. Nos experimentos preliminares, quando $10 \%$ de ácido capróico (em relação à massa seca de proteína) foi utilizado, foi observada forte exudação do ácido graxo na superfície do filme, o que determinou sua inclusão ao nível de $5 \%$ em todas as formulações estudadas. Segundo McHUGH e KROCHTA ${ }^{18}$ com o aumento das cadeias de ácidos 
Tabela 1. Caracterização da permeabilidade ao vapor de água (PVA), opacidade (OP) e suas propriedades mecânicas (Resistência à tração, RT e Elongação, Elon).

\begin{tabular}{|c|c|c|c|c|c|}
\hline Formulações & Espessura (mm) & PVA (g.mm/m²d.KPa) & OP (\%) & RT (MPa) & Elon (\%) \\
\hline $\mathrm{Gel} / \operatorname{tri} / \mathrm{AE}$ & $0,093 \pm 0,002$ & $8,2 \pm 0,3^{b}$ & $19,1 \pm 0,1^{\mathrm{ac}}$ & $53,4 \pm 1,4^{\mathrm{e}}$ & $3,6 \pm 0,9^{\text {de }}$ \\
\hline $\mathrm{Gel} / \operatorname{tri} / \mathrm{AE}(\mathrm{pH})^{* *}$ & $0,091 \pm 0,002$ & $2,4 \pm 0,3^{\mathrm{de}}$ & $17,2 \pm 0,3^{\text {bd }}$ & $65,8 \pm 0,6^{\mathrm{d}}$ & $4,7 \pm 0,8^{\mathrm{cd}}$ \\
\hline $\mathrm{Gel} / \operatorname{tri} / \mathrm{AC}$ & $0,089 \pm 0,001$ & $9,5 \pm 0,5^{\mathrm{a}}$ & $14,5 \pm 0,4^{\text {cde }}$ & $124,3 \pm 1,4^{\mathrm{a}}$ & $7,0 \pm 0,6^{a}$ \\
\hline $\mathrm{Gel} / \operatorname{tri} / \mathrm{AC}(\mathrm{pH})^{* *}$ & $0,088 \pm 0,002$ & $7,1 \pm 0,3^{\mathrm{bc}}$ & $16,2 \pm 0,5^{\mathrm{bcd}}$ & $112,3 \pm 0,5^{\mathrm{b}}$ & $5,6 \pm 0,4^{\mathrm{b}}$ \\
\hline Gel/tri/AC/10\%Tween* & $0,090 \pm 0,003$ & $6,7 \pm 0,5^{\mathrm{bc}}$ & $13,2 \pm 0,3^{\mathrm{efg}}$ & $100,4 \pm 1,2^{\mathrm{c}}$ & $4,4 \pm 1,2^{\text {cd }}$ \\
\hline Gel/tri/AC/10\%Tween*(pH)** & $0,089 \pm 0,002$ & $4,4 \pm 0,6^{\mathrm{bc}}$ & $14,2 \pm 0,2^{\mathrm{def}}$ & $101,3 \pm 1,4^{\mathrm{c}}$ & $6,3 \pm 0,6^{\mathrm{ab}}$ \\
\hline Gel/tri/AC/10\%SDS* & $0,090 \pm 0,001$ & $4,7 \pm 0,2^{\mathrm{bc}}$ & $20,2 \pm 0,5^{\mathrm{bc}}$ & $95,1 \pm 0,9^{\text {ac }}$ & $5,6 \pm 0,2^{\mathrm{bd}}$ \\
\hline Gel/tri/AE/70\%SDS* & $0,095 \pm 0,006$ & $1,9 \pm 0,4^{\mathrm{e}}$ & $24,4 \pm 0,7^{\text {ba }}$ & $31,1 \pm 0,9^{\text {cf }}$ & $3,3 \pm 0,9^{\mathrm{de}}$ \\
\hline $\mathrm{Gel} / \operatorname{tri} / \mathrm{AE} / 60 \% \mathrm{SDS}^{*}(\mathrm{pH})^{* *}$ & $0,093 \pm 0,004$ & $2,5 \pm 0,5^{\mathrm{de}}$ & $22,0 \pm 0,6^{\mathrm{b}}$ & $12,1 \pm 1,2^{\mathrm{fg}}$ & $1,7 \pm 0,6^{\mathrm{ef}}$ \\
\hline Gel/tri/AE/100\% Tween* & $0,094 \pm 0,005$ & $8,3 \pm 0,4^{b}$ & $16,8 \pm 0,4^{\mathrm{efd}}$ & $21,1 \pm 0,9^{g}$ & $3,8 \pm 1,1^{\text {de }}$ \\
\hline PVC & - & - & 12,2 & - & - \\
\hline
\end{tabular}

Gel: Gelatina; tri: triacetina; AC: ácido capróico; e AE: ácido esteárico. Média e desvio das triplicatas. *\%de surfactante total adicionado em relação à quantidade de gelatina (base seca). **Ajuste de pH. Letras em comum na mesma coluna não apresentam diferença significativa a p $\leq 0,05$, entre as médias obtidas através do teste de TUKEY.

graxos a porção apolar de cada molécula também aumenta, resultando em menor permeabilidade ao vapor de água aos filmes emulsionados. PEROVAL et al. ${ }^{23}$ também constataram que a permeabilidade ao vapor de água dos filmes de arabinoxilana com ácido esteárico foi menor que a dos filmes com a adição de ácido palmítico. Novamente McHUGH, AUJARD e $\mathrm{KROCHTA}^{19}$ em outro trabalho, verificaram que a presença de ácido esteárico em filmes de proteína do soro do leite reduziu a mobilidade protéica, formando um filme viscoelástico na interface lipídio-água, diminuindo a difusidade da água através da proteína interfacial e promovendo um menor valor de permeabilidade ao vapor de água.

A correção do $\mathrm{pH}$ influiu nos valores de PVA obtidos para ambos os filmes, tanto com ácido esteárico ou ácido capróico, provocando uma diminuição significativa $(\mathrm{p}<0,05)$ da PVA para os filmes, sendo que a redução mais acentuada ocorreu para o filme adicionado de ácido esteárico, que apresentou valores de 8,20 g.mm.m. ${ }^{-2}$ d.KPa sem ajuste de pH, e 2,42 g.mm.m ${ }^{-2}$ d.KPa com o pH ajustado. De acordo com YOSHIDA ${ }^{29}$, o aumento da hidrofobicidade, representada pela concentração de ácido esteárico, provocou a redução na permeabilidade ao vapor de água, com valores menores para filmes de proteína do soro de leite obtidos em $\mathrm{pH}$ básico $(9,0)$ do que em $\mathrm{pH}$ neutro. $\mathrm{O}$ aumento do pH, devido à adição do hidróxido de sódio, pode provocar uma saponificação dos ácidos graxos, melhorando a incorporação destes no filme e conseqüentemente, reduzindo a permeabilidade ao vapor de água. Uma outra explicação para a maior PVA nos filmes em pH ácido, segundo PÉREZ-GAGO e $\mathrm{KROCHTA}^{22}$, é que a capacidade de emulsificação e a habilidade de formação de filme no isolado protéico de soro de leite em $\mathrm{pH}$ ácido foram reduzidas, devido a mudanças conformacionais das proteínas do soro.

A adição de surfactantes também influenciou na PVA dos filmes. Os filmes com ácido capróico e 10\% Tween 80 ou com $10 \%$ SDS tiveram significativamente $(\mathrm{p} \leq 0,05)$ menor PVA (6,7 e 4,7 g.mm.m.2 ${ }^{-2}$.KPa, respectivamente) em comparação ao filme de ácido capróico sem a adição de surfactantes (9,5 g.mm. m $^{-2}$ d.KPa). Assim, tanto o surfactante SDS quanto o Tween 80 foram eficientes na redução da PVA desses filmes, talvez por terem melhorado a estabilidade das partículas de lipídio na matriz protéica ${ }^{5}$. O filme com ácido esteárico e $70 \%$
SDS apresentou um dos valores mais baixos de permeabilidade ( 1,9 g.mm. $\mathrm{m}^{-2} \mathrm{~d} . \mathrm{KPa}$ ) deste estudo, valor um quarto menor do que para o filme sem a adição do surfactante, observado-se que o surfactante SDS foi mais efetivo na diminuição da permeabilidade ao vapor de água para esse filme. Esse mesmo comportamento foi observado por RHIM et al. ${ }^{24}$, para filmes de isolado protéico de soja e 10\% SDS, efeito atribuído às porções hidrofóbicas das moléculas de SDS, que diminuíram a taxa de sorção e difusão das moléculas de água através das estruturas do filme. Por outro lado, o surfactante Tween 80 não foi efetivo para o filme contendo ácido esteárico, pois não alterou a PVA, em relação a esse filme sem surfactante (Tabela 1). DEBEAUFORT e VOILLEY ${ }^{10}$ verificaram que a eficiência da emulsificação depende principalmente da natureza química do surfactante e não tanto do valor de HLB (balanço hidrofílico-lipofílico). A permeabilidade dos filmes biodegradáveis depende fortemente da estrutura do filme, por exemplo, do tamanho e da homogeneidade da distribuição de glóbulos de gordura no filme.

Para as formulações com adição de surfactantes e ajuste de $\mathrm{pH}$, foi observada diminuição significativa $(\mathrm{p} \leq 0,05)$ da permeabilidade devido ao ajuste do $\mathrm{pH}$ para os $\mathrm{Gel} / \mathrm{tri} / \mathrm{AC} / 10 \%$ Tween e Gel/tri/AE/60\%SDS, como pode ser visto na Tabela 1, comparado aos filmes sem surfactantes e sem ajuste de $\mathrm{pH}$.

\subsection{Propriedades mecânicas}

As propriedades mecânicas dos filmes dependem das interações entre os componentes, ou seja, da formação de ligações moleculares fortes ou numerosas entre as cadeias ${ }^{9}$.

Os filmes compostos com ácido esteárico (18C) apresentaram significativamente menor resistência mecânica (53, 4 MPa), em oposição aos filmes compostos com ácido capróico (6C), que apresentaram resistência mecânica de 124,3 MPa, quando as formulações básicas (sem ajuste de $\mathrm{pH}$ e sem adição de surfactantes) foram comparadas (Tabela 1). Isso possivelmente ocorreu devido ao tamanho das cadeias de carbono dos ácidos graxos, e à menor quantidade de ácido capróico adicionada à solução filmogênica em comparação com o ácido esteárico; o ácido de menor cadeia pode ter desestruturado menos a cadeia da gelatina, obtendo-se uma resistência mecânica maior no filme resultante. A diminuição da tensão na ruptura com o 
aumento da concentração de ácido esteárico foi associada por YANG e PAULSON ${ }^{28}$, aos grupos carboxil presentes nas moléculas de ácido esteárico, que competem com as moléculas de proteína, reduzindo as interações entre os polímeros e, conseqüentemente, enfraquecendo a tensão de ruptura do filme.

A correção do $\mathrm{pH}$ influiu nos valores de tensão de ruptura obtidos, tanto para os filmes de ácido esteárico, como para os filmes com o ácido capróico, porém com efeitos inversos, já que os filmes com ácido esteárico apresentaram um aumento significativo $(\mathrm{p}<0,05)$ da tensão de ruptura, e os filmes com ácido capróico apresentaram uma diminuição significativa $(\mathrm{p}<0,05)$ na tensão de ruptura. Segundo YOSHIDA e ANTUNES $^{30}$, a incorporação de lipídios em filmes protéicos resulta em um aumento na tensão de ruptura, indicando que o filme encontra-se heterogêneo; entretanto, quando o pH é ajustado para 7,0, os filmes apresentam-se mais estáveis e fortes. Segundo DEBEAUFORT e VOILLEY ${ }^{10}$, um filme com estrutura heterogênea apresenta descontinuidades na rede, que aumentam a fragilidade do filme, devido a pontos preferenciais de quebra.

Com relação à adição de surfactantes nos filmes, verificou-se que o aumento na concentração do surfactante reduziu significativamente $(\mathrm{p}<0,05)$ a resistência mecânica dos filmes. Este mesmo efeito foi anteriormente observado por RHIM et al. ${ }^{24}$, a adição de $40 \%$ de SDS reduziu substancialmente as propriedades de tensão dos filmes de isolado protéico de soja. Segundo eles, essa redução na resistência mecânica nos filmes com SDS parece estar relacionada com a formação de estruturas mais fracas devido à falta de interações hidrofóbicas nas proximidades das cadeias moleculares de proteína, favorecendo interações hidrofóbicas SDS-proteína. Já o ajuste de pH no filme de ácido esteárico com SDS reduziu mais da metade do valor da resistência mecânica, tornando assim o filme mais fraco, com a menor RT entre todos os filmes estudados.

Para a elongação nas formulações básicas dos filmes de gel/ tri/AE e Gel/tri/AC, foram observados valores estatisticamente diferentes ( $\mathrm{p}<0,05)$ : o filme com ácido esteárico apresentou uma elongação de 3,6\% e o filme com ácido capróico, de 7,0\%. As mudanças nesta propriedade caracterizam modificações na organização tridimensional, decrescendo a densidade e reversibilidade das interações intermoleculares ocorridas na rede protéica formadora do filme e aumentando o volume vazio e a mobilidade da cadeia ${ }^{11}$.

$\mathrm{O}$ ajuste de $\mathrm{pH}$ nessas formulações diferenciou significativamente $(\mathrm{p}<0,05)$ os filmes com ácido esteárico dos filmes com ácido capróico, sendo que os filmes com ácido esteárico apresentaram maior elongação quando o pH foi ajustado, e os filmes com ácido capróico apresentaram menor elongação sob efeito do $\mathrm{pH}$ (Tabela 1).

Para as formulações com adição de surfactantes, a formulação Gel/tri/AE com SDS nas concentrações de $70 \%$ e $60 \%(\mathrm{pH})$ apresentaram valores de elongação significativamente ( $p<0,05$ ) diferentes. Na formulação de $60 \% \mathrm{SDS}(\mathrm{pH})$, na qual foi efetuado o ajuste de $\mathrm{pH}$, observou-se o menor valor de elongação entre todas as formulações estudadas (Tabela 1).

\subsection{Opacidade}

Para os filmes com formulações básicas, houve diferença significativa ( $\mathrm{p}<0,05$ ) na opacidade, sendo que os filmes com o ácido esteárico foram mais opacos do que os filmes com o ácido capróico. Isso possivelmente deve ter ocorrido pela maior quantidade de ácido esteárico utilizado na formulação (Tabela 1) em comparação ao ácido capróico. Segundo BATISTA ${ }^{6}$, os filmes combinados de pectina e gelatina apresentaram-se mais opacos com a adição dos ácidos graxos.

$\mathrm{O}$ ajuste de $\mathrm{pH}$ para os filmes com o ácido esteárico diminuiu significativamente $(\mathrm{p}<0,05)$ a opacidade do filme; enquanto para os filmes com o ácido capróico, não foi observada diferença significativa, e, adicionalmente, a opacidade de ambos os filmes foi maior em relação ao filme de PVC utilizado como referência.

A adição do surfactante SDS provocou aumento na opacidade, tanto nos filmes com ácido esteárico, como também nos filmes com ácido capróico. Segundo $\mathrm{RHIM}^{24}$, filmes de isolado protéico de soja contendo grandes quantidades de SDS (10, 20 e 40\%) apresentaram menor transparência do que os filmes sintéticos, apresentando-se com uma aparência mais amarelada, o que foi atribuída à cor inerente do SDS, que não foi considerada visualmente prejudicial.

O ajuste de $\mathrm{pH}$ nos filmes adicionados de surfactantes não modificou significativamente a opacidade de nenhum filme, porém a adição dos ácidos graxos e dos surfactantes de uma forma geral, tornou os filmes mais opacos em relação ao filme de PVC.

\subsection{Microscopia eletrônica de varredura}

A microscopia eletrônica de varredura de um filme busca correlacionar as propriedades físico-químicas com sua estrutura morfológica ${ }^{17,19,8,13}$.

Para o filme com ácido esteárico sem o ajuste de pH (Figura 1a), a morfologia de superfície apresentou claramente a presença das gotas de óleo na matriz filmogênica, evidenciando a não incorporação do ácido esteárico na matriz protéica. O ajuste do $\mathrm{pH}$, por sua vez, melhorou a dispersão da substância hidrofóbica na matriz, com diminuição nítida do tamanho das gotas de gordura (Figura 1b). WONG et al. ${ }^{27}$, trabalhando com a adição de ácidos graxos em soluções filmogênicas de quitosana, observaram que a adição de compostos hidrofóbicos provocava modificação na morfologia de superfície dos filmes e, em decorrência disso, alterações na permeabilidade à água dos filmes resultantes.

Na superfície dos filmes com ácido capróico, com e sem o ajuste de pH (Figuras 1c e 1d), foi possível também observar gotículas dispersas, causando irregularidades na matriz filmogênica, indicando que o ajuste de $\mathrm{pH}$ nesse caso não melhorou a incorporação de forma homogênea do ácido capróico.

Após a adição dos surfactantes nos filmes com ácido esteárico, foi possível observar uma mudança estrutural nas matrizes filmogênicas, em relação às matrizes sem a adição dos tensoativos. Para o filme com ácido esteárico e 70\% de SDS 

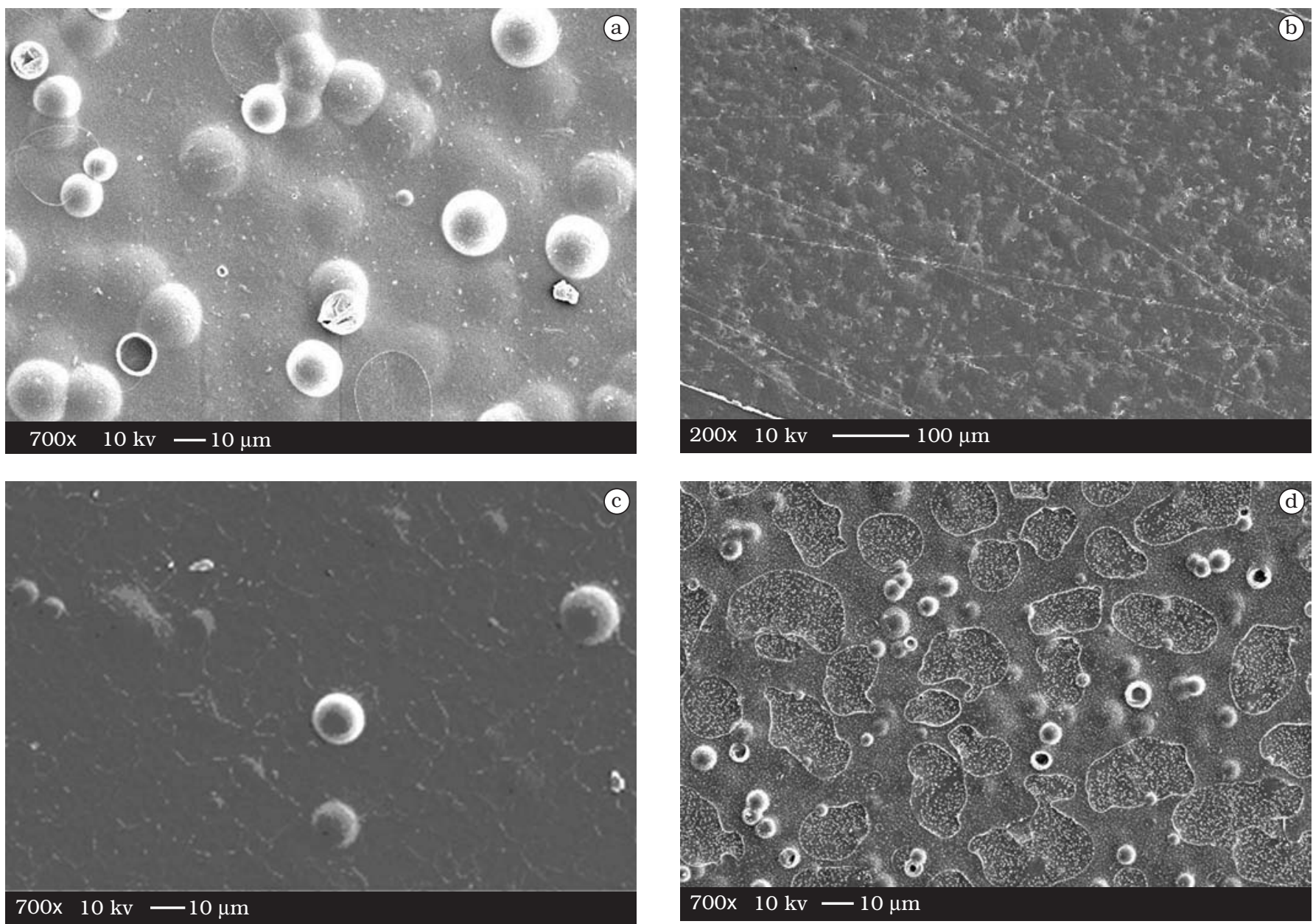

Figura 1. Microscopia eletrônica de varredura dos filmes de: a) gelatina, triacetina e ácido esteárico; b) gelatina, triacetina e ácido esteárico, com ajuste de $\mathrm{pH}$; c) gelatina, triacetina, ácido capróico; e d) gelatina, triacetina, ácido capróico, com ajuste de pH.

(Figura 2a), a matriz polimérica apresentou-se sem gotas de gordura, quando comparada com as formulações sem a adição deste surfactante (Figura 1a). Na Figura 2b, o filme com ácido esteárico e $60 \%$ de SDS (com ajuste de $\mathrm{pH}$ ) apresentou uma mudança na morfologia, não sendo visíveis as gotas de gordura, indicando que o surfactante foi eficiente na incorporação do ácido esteárico na matriz filmogênica, em comparação ao filme sem SDS (Figura 1a). Isso pode explicar a baixa permeabilidade ao vapor de água obtida para este filme (Tabela 1), porém a superfície apresenta-se ainda irregular indicando a presença de rachaduras no filme.

\subsection{Microscopia confocal de varredura a laser (MCLV)}

O biofilme composto de gelatina, triacetina e ácido esteárico, ilustrado na Figura 3a apresentou dispersão de gotas de óleo na matriz filmogênica, onde o ácido esteárico pode ser observado, indicando a heterogeneidade do filme, o que também foi observado através da microscopia eletrônica de varredura (Figura 1a), e que possivelmente resultou no alto valor de permeabilidade ao vapor de água obtido para este filme (8,2 g.mm.m-2 d.Kpa, Tabela 1). Resultados semelhantes foram observados por BERTAN ${ }^{7}$. Nas imagens dos filmes compostos (gelatina, triacetina e ácidos esteárico e palmítico), gotas dos ácidos graxos foram observadas separadas da matriz protéica, sugerindo um material heterogêneo, contendo duas fases, a matriz polimérica e a fase de ácidos graxos.

O filme composto de gelatina, triacetina e ácido esteárico, com o pH ajustado conforme observado na Figura 3b, apresentou uma dispersão maior das gotas de gordura, comparado ao filme sem ajuste de $\mathrm{pH}$ (Figura 3a), indicando que o ajuste do $\mathrm{pH}$ provavelmente ajudou na maior homogeneização lipídica na matriz filmogênica, provocando uma melhor incorporação do ácido graxo na mesma. O efeito foi também corroborado pela microscopia eletrônica de varredura (Figura 1b) e pelo baixo valor de permeabilidade ao vapor de água obtido para esta formulação (2,4 g.mm.m² d.KPa, Tabela 1$)$.

A morfologia do biofilme de gelatina, triacetina e ácido capróico apresentada na Figura 3c, indica que o ácido capróico não foi bem incorporado na matriz filmogênica, mesmo estando presente em menor quantidade $(5 \%$ em relação à massa seca de gelatina) em relação à formulação contendo ácido esteárico (10\% em relação à massa seca de gelatina). O efeito foi também observado através da microscopia eletrônica de varredura (Figura 1c). $\mathrm{O}$ ajuste de $\mathrm{pH}$ para o filme contendo o ácido capróico 

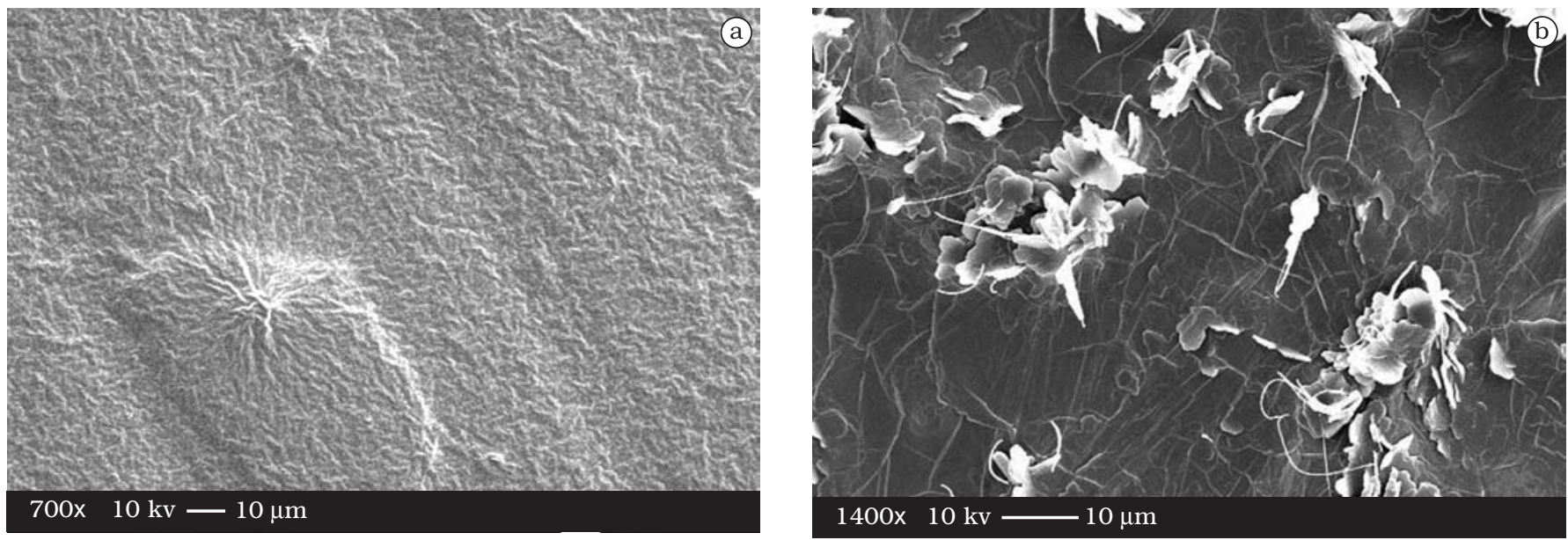

Figura 2- Microscopia eletrônica de varredura da superfície dos filmes de: a) gelatina, triacetina, ácido esteárico e 70\% de SDS; e b) gelatina, triacetina, ácido esteárico e $60 \%$ de SDS, com ajuste de pH.
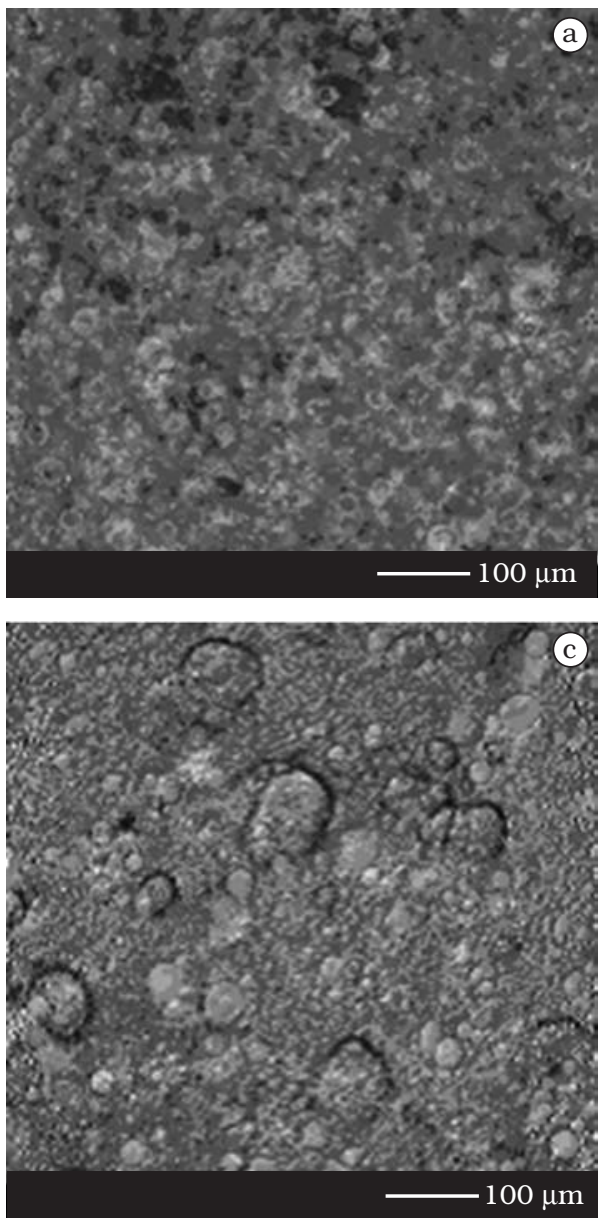
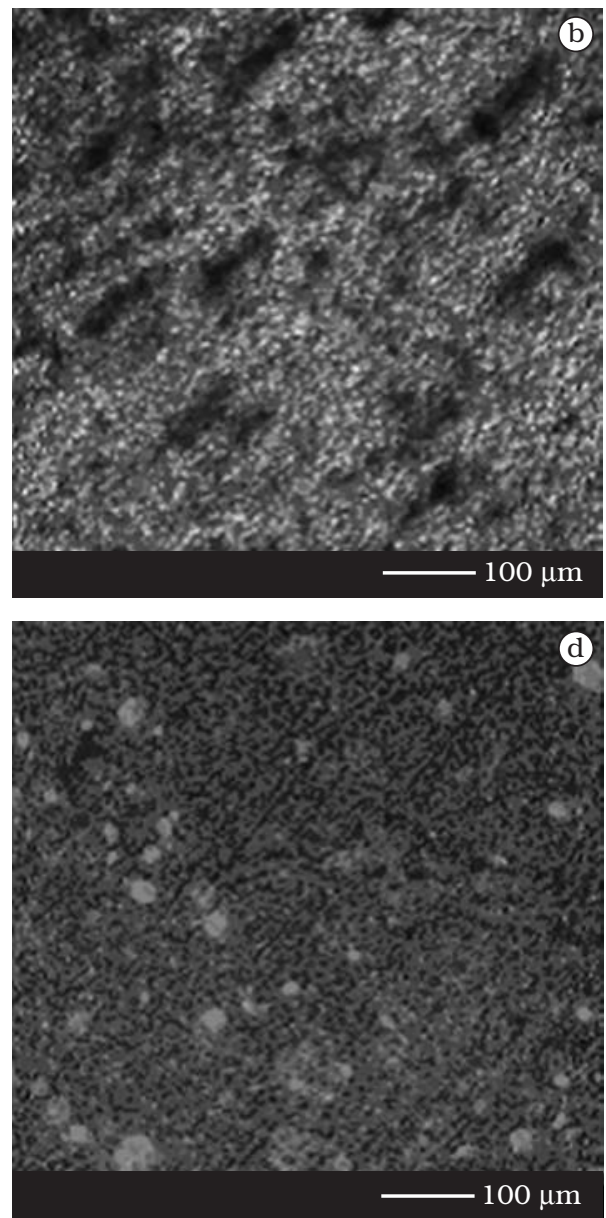

Figura 3. Microscopia confocal a laser. a) filme de gelatina, triacetina e ácido esteárico, sem ajuste de pH; b) filme de gelatina, triacetina e ácido esteárico com ajuste de $\mathrm{pH}$; c) filme de gelatina, triacetina e ácido capróico sem ajuste de $\mathrm{pH}$; e d) filme de gelatina, triacetina e ácido capróico com ajuste de $\mathrm{pH}$.

(Figura 3d) parece também ter possibilitado um aumento não integral, na incorporação do conjunto hidrofóbico à matriz protéica quando se comparam a Figuras 3c e 3d, evidenciando a diminuição das gotas de lipídio sob efeito do ajuste de $\mathrm{pH}$, efeito também observado quando a microscopia eletrônica de varredura (Figura 1d) foi utilizada.
Filmes contendo ácido esteárico adicionados dos surfactantes podem ser observados na Figura 4a,b, onde é possível notar que houve uma melhora na incorporação das substâncias hidrofóbicas, sendo visível a ausência das gotas de gordura, comparados aos filmes sem a adição de surfactantes (Figuras 3a e 3c). Isto possivelmente pode ter resultado 
na baixa permeabilidade ao vapor de água que estes filmes apresentaram (1,9 e 2,5 g.mm.m ${ }^{-2}$ d.Kpa, respectivamente, Tabela 1).
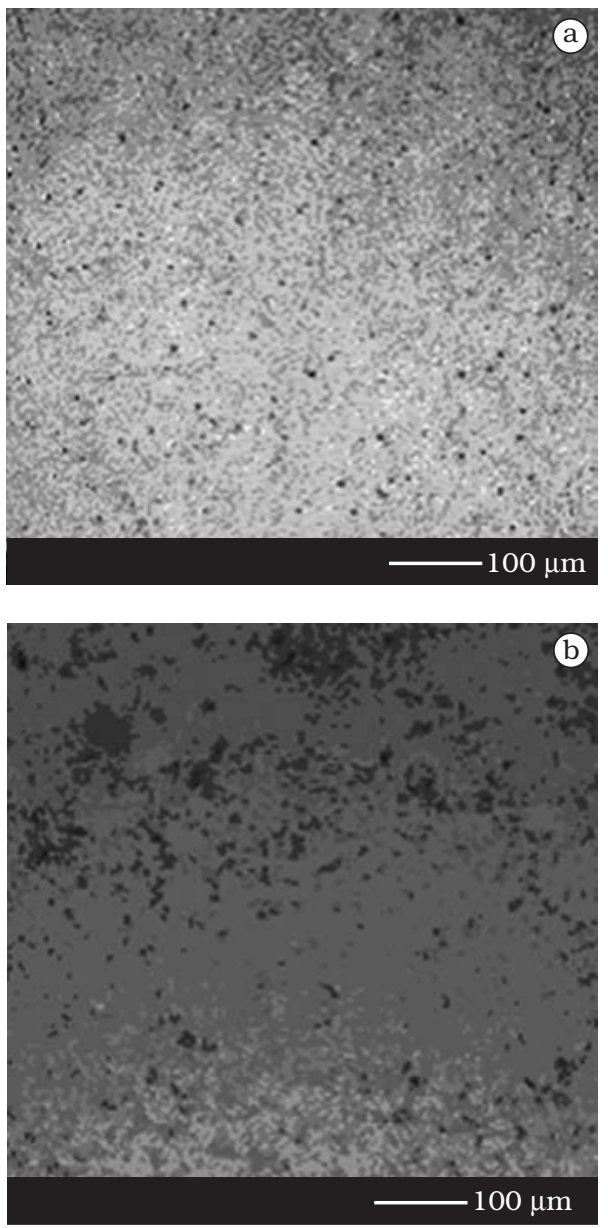

Figura 4. Microscopia confocal a laser. a) filme de gelatina, triacetina, ácido esteárico e $70 \%$ SDS; e b) filme de gelatina, triacetina, ácido esteárico e $60 \%$ SDS, com ajuste de pH.

\section{Conclusões}

A adição do ácido graxo de maior cadeia (ácido esteárico$18 \mathrm{C}$ ) e em maior quantidade (10\% em relação à massa seca de gelatina) nos filmes à base de gelatina resultou em menor permeabilidade ao vapor de água, quando comparado ao filme com ácido graxo de cadeia menor (ácido capróico-6C). Por outro lado, os filmes com o ácido capróico apresentaram melhor resistência mecânica do que os filmes contendo o ácido esteárico.

$\mathrm{O}$ ajuste de $\mathrm{pH}$ para os filmes sem a adição de surfactantes foi eficiente na redução da permeabilidade ao vapor de água em comparação aos filmes produzidos no $\mathrm{pH}$ natural da solução filmogênica. Este efeito pode também ser observado através das morfologias dos filmes (microscopia eletrônica de varredura e confocal), produzindo matrizes visualmente mais homogêneas.
A adição do surfactante SDS mostrou-se eficiente na diminuição da permeabilidade ao vapor de água dos filmes. O efeito melhora conforme aumenta sua concentração na solução filmogênica. Por outro lado, o aumento da concentração deste surfactante provoca perda nas propriedades mecânicas. Já o surfactante Tween 80 só foi eficiente na redução da permeabilidade ao vapor de água dos filmes com ácido capróico e ainda com ajuste de pH. A utilização de compostos tensoativos naturais presentes em alimentos pode ser uma boa alternativa aos tensoativos sintéticos, uma vez que os tensoativos naturais apresentam maior significância biológica, portanto seu efeito sobre a funcionalidade dos filmes deve ser estudado. $\mathrm{O}$ uso de surfactantes em sistemas de dissolução para compostos insolúveis pode ser fisiologicamente mais significante por causa da presença de surfactantes naturais como ácidos biliares e lecitina no trato gastrointestinal humano ${ }^{26}$.

\section{Referências bibliográficas}

1. AMARANTE, C.; BANKS, N. H. Postharvest physiology and quality of coated fruits and vegetables. J. Horticultural Reviews, v. 26, p. 161-238, 2001.

2. ANKER, M.; STADING, M.; HERMANSSON, A. Aging of whey protein films and the effect on mechanical and barrier properties. Journal of Agricultural and Food Chemistry, v. 49, n. 2, p. 989-995, 2001.

3. ASTM. Standard test methods of water vapor transmission of materials. American Society for Testing and Materials, Philadelphia, E 96-95, 1995

4. ASTM. Tensile properties of thin plastic sheeting. Annual Book oh ASTM Standards, Philadelphia: American Society for Testing and Materials, D 882, 1995.

5. BALDWIN, A. et al. Use of lipids in coatings for food products. Food Technology, v. 51, n. 6, p. 56-62, 1997.

6. BATISTA J. A. Desenvolvimento, Caracterização e Aplicações de Biofilmes a base de Pectina, Gelatina e Ácidos Graxos em bananas e sementes de brócolos. 2004. 149 f. Dissertação (Mestrado em Alimentos e Nutrição) - Faculdade de Engenharia de Alimentos, Universidade Estadual de Campinas, Campinas, 2004.

7. BERTAN, L. C. Desenvolvimento e caracterização de filmes simples e compostos a base de gelatina, ácidos graxos e breu branco. 2003. 148 f. Dissertação (Mestrado em Alimentos e Nutrição) - Faculdade de Engenharia de Alimentos, Universidade Estadual de Campinas, Campinas, 2003.

8. BRANDENBURG, A. H.; WELLER, C. L.; TESTIN, R. F. Edible films and coatings from soy protein. Journal of Food Science, v. 58, n. 5, p. 1086-1089, 1993.

9. CALLEGARIN, F. et al. Lipids and Biopackaging. Journal of American Oil Chemistry Society, v. 74, n. 10, p. 1183-1192, 1997.

10. DEBEAUFORT, F; VOILLEY, A. Effect of surfactants and drying rate on barrier properties of emulsified edible films. International Journal of Food Science and Technology, v. 30, p. 183-190, 1995.

11. GALIETTA, G. et al. Mechanical and thermomechanical properties of films based on whey proteins as affected by plasticizer na crosslinking agents. Journal of Dairy Science, v. 81, n. 12, p. 3123-3130, 1998. 
12. GONTARD, N. et al. Edible composite films of wheat and lipids: water vapour permeability and other physical properties. International Journal of Food Science and Technology, v. 29, p. 39-50, 1994.

13. GREENER, I. K.; FENNEMA, O. Evaluation of edible, bilayer films for use as moisture barriers for food. Journal of Food Science, Chicago, v. 54, n. 6, p. 1400-1406, 1989.

14. HUNTERLAB. The color management company. Universal software, version 3.2 Reston, 1997.

15. JANGCUHD, A; CHINNAN, M. S. Properties of peanut protein film: sorption isotherm and plasticizer effect. LebensmittelWissenschaft and Technologie, v. 32, n. 1, p. 89-94, 1999.

16. LAMPRECHT, A; SCHAFFER, U. F.; LEHR, C-M. Characterization of microcapsules by confocal laser scanning microscopy: strututre, capsule wall composition and encapsulation rate. European Journal of Pharmaceutics and Biopharmaceutics., v. 49 , p. 1-9, 2000.

17. MAUER, L. J.; SMITH, D. E.; LABUZA, T. P. Water vapor permeability, mechanical, and structural properties of edible B-casein films. International Dairy Journal, v. 10, n. 5-6, p. 353-358, 2000.

18. McHUGH, T. H.; KROCHTA, J. M. Milk-protein-based edible films and coating. Food Technology, v. 48, n. 1, p. 97-103, 1994

19. McHUGH, T. H.; AUJARD, J-F.; KROCHTA, J. M. Plasticized whey protein edible films: water vapor permeability properties. Journal of Food Science, v. 59, n. 2, p. 416-419 e 423, 1993.

20. MINATTI, E. Um novo modelo para a interação entre polímeros neutros hodrossolúveis e surfactantes. 2005. Tese (Doutorado em Ciências Físicas e Matemáticas), Departamento de Guímica - Universidade Federal de Santa Catarina, Florianópolis.
21. MORILLON, V. et al. Influence of the physical state of water on the barrier properties of hydrophilic films. Journal of Agricultural and Food Chemistry, v. 48, n. 1, p. 11-16, 2002

22. PÉREZ-GAGO, M. B.; KROCHTA, J. M. Water vapor permeability of whey protein emulsion films as affected by pH. Journal of Food Science, v. 64, n. 4, p. 695-698, 1999.

23. PEROVAL, C. et al Edible arabinoxylan-based films. 1. Effects of lipids types on water vapor permeability, film structure, and other physical characteristics. Journal of Agricultural and Food Chemistry, v. 50, p. 3977-3983, 2002.

24. RHIM, J. A. et al. Sodium dodecyl treatment improves properties of cast films from soy protein isolate. Industrial Crops and Products, v. 15, p. 199-205, 2002.

25. SAS. Statistical Analytical System. SAS Institute Inc; SAS Campus Drive, Cary, North Caroline, USA, Version 6.12, 2004.

26. SHAH, N. P. et al. In vitro dissolution profile of water-insoluble day dosage forms in the presence of surfactants. Pharmaceutical Research, v. 9, n. 7, p. 612-618, 1989.

27. WONG, D. W. S. et al. Edible chitosan-lipid films: Microestructure and surface energy. Journal of Agriculture and Food Chemistry, v. 40 , p. $540-544,1992$

28. YANG, L.; PAULSON, A. T. Mechanical and water barriers properties of edible gellan film. Food Reserch International, v. 33, n. 7, p. 563-570, 2000.

29. YOSHIDA, C. M. P. A. Aplicação de concentrado protéico de soro de leite bovino na elaboração de filmes comestíveis. 2002. 227 f. Tese (Doutorado em Alimentos e Nutrição) - Faculdade de Engenharia de Alimentos, Universidade Estadual de Campinas, Campinas, 2002.

30. YOSHIDA, C. M. P; ANTUNES A. J. Characterizacion of whey protein emulsion films. Brazilian Journal of Chemical Engineering. v. 21, n. 2, p. 247-252, 2004. 